\title{
30 years of research on insect galls in Brazil: a scientometric review
}

\author{
Walter Santos de Araújo ${ }^{1}$ \\ 1 Universidade Estadual de Montes Claros (UNIMONTES), Centro de Ciências Biológicas e da Saúde (CCBS), Departamento de Biologia Geral. \\ Montes Claros, MG, Brasil. ORCID: 0000-0003-0157-6151. E-mail: walterbioaraujo@yaho0.com.br
}

\begin{abstract}
The first systematic studies on insect galls in Brazil date to the early $20^{\text {th }}$ century, after which research on insect galls remained dormant in the country, with interest not reviving until the 1980s. The aim of this study was is to document historical trends in publications about insect galls in Brazil over the last 30 years. Papers about insect galls and galling species in Brazil published in peer-reviewed journals from 1988 to 2017 were compiled. A total of 1,378 papers were analyzed, of which 182 addressed insect galls in Brazil. The results showed that the number of publications on the subject has been increasing over the last 30 years, and especially in the last decade. The diversity of journals that published on the subject has also been increasing. The studies were concentrated on the following topics: ecology (94 papers), inventory (29) and taxonomy (27). Most of the insect gall inventories in Brazil took place in the Southeast Region (29 papers), followed by the Central-West and Northeast regions, with eight papers each. This study documents a trend toward increasing scientific production on insect galls in Brazil, but with significant geographical bias: the researchers involved are concentrated in the Southeast Brazilian region.
\end{abstract}

Key-Words. Ecological interaction; Galling insects; Plant-insect interaction; Scientometry.

\section{INTRODUCTION}

Galling insects are very diverse, with some estimates indicating that there could be as many as 132,000 species on the planet (Espírito-Santo \& Fernandes, 2007), and between 5,540 (GrandezRios et al., 2015) and 9,282 species (Araújo et al., 2014) in Brazil. Although reports on insect galls in Brazil have been published since the $19^{\text {th }}$ century, the first systematic studies involving them date to the early 20 $0^{\text {th }}$ century (Moreira, 2006). From 1905 to 1925 , important natural historians, such as J.S. Tavares (Portugal), E.H. Rübsaamen (Germany), and E.P. Felt (United States of America - USA), described a large number of galling insect species from Brazil (Maia, 2005). After this period, the study of insect galls in Brazil remained dormant, with interest in the group not reviving until the 1980s. Since then, studies on galling insects have been carried out in different regions of Brazil using a variety of approaches and focusing on topics such as anatomy, biology, ecology and taxonomy (Moreira, 2006).

Brazil is the current leader in scientific production regarding insect galls, together with Mexico and USA (Grandez-Rios et al., 2015). The aim of the present study was to identify historical trends in the research on insect galls in Brazil over the last 30 years. Publications from 1988 to 2017, available in different scientific journal databases, were compiled. The main features of the papers were described and historical trends assessed with regard to number of papers, journals publishing on the subject, quality of the publications, topics investigated and the most studied regions and states of Brazil. The evaluation of scientific production in natural sciences has been the topic of discussion in recent years (Brito et al., 2009; Nabout et al., 2012; Borges et al., 2015; Nabout et al., 2015; Vaz et al., 2015; Santos et al., 2017), and has become an important tool for identifying trends and biases in the scientific production of a given area of study (Drew et al., 2016).

\section{MATERIALS AND METHODS}

Papers about insect galls and galling species in Brazil published in peer-reviewed journals from 1988 to 2017 were compiled from papers indexed in the platform "Portal de Periódicos Capes" (www. periodicos.capes.gov.br). This platform includes several scientific databases such as SCOPUS and Scielo, which makes a more comprehensive search on the topic possible. The period analyzed in this study (1988-2017) begins in the 1980s, when gall studies were again becoming frequent in Brazil (Moreira, 2006). The search for papers was done in September of 2017 using the key-words "insect*" and "gall*" in the title, abstract or list. The resulting papers had their titles and abstracts (and when necessary the full text) inspected to filter out only studies on galling insects in Brazil. Thus, papers were included in the compilation only when it was explicitly indicated that the study was fully or partially performed within Brazil. 
The selected papers were sorted by year and journal. The historical trend in the number of publications per year was evaluated using Pearson correlation $(P<0.05)$. The diversity of journals that published papers on the subject from 1988 to 2017 was evaluated using the Shannon-Wiener diversity index $\left(\mathrm{H}^{\prime}\right)$. This index is frequently used in ecological studies but has also been applied to estimate journal diversity over time in scientometric studies (e.g., Nabout et al., 2012; Vaz et al., 2015). Pearson correlation was then used to evaluate the relationship between the journal diversity index and year. Journals were ranked by importance according to the number of papers published on the subject.

All compiled papers were classified according to topic - the area(s) of knowledge they best matched - by inspecting the title and the abstract (or the full text if necessary). The topics included: agriculture (focusing on agricultural pests), botanical anatomy (anatomical, morphological and histochemical focus on galls), ecology (investigating ecological factors at population, community or biogeographical levels), genetics (genetic diversity), inventory (checklists of galls and host plants), taxonomy (focusing on systematics, descriptions and revisions of galling species) and reviews (compiling data from the literature or purely theoretical treatments). Papers that fit more than one topic were counted in each. The number of citations of each paper was also determined through the SCOPUS database (www.scopus.com), and compared among topics using ANOVA and among years using linear regression.

To give an overview of the distribution of papers identified as inventories, papers were classified by location (Brazilian region and state) according to the content and the description of the authors. This was done by obtaining data from the Portal de Periódicos Capes database and performing an additional search (through Google Scholar and bibliographies in the compiled papers). Papers were considered inventories only if they presented primary data and sampled the community of host plants. Studies that inventoried the diversity of insect galls of only one species of host plant were classified under the topic "ecology". Studies that compiled information on the occurrence of insect galls from secondary data (literature or museums) were considered under the topic "review". Inventories carried out in more than two Brazilian states were included under each state involved.

\section{RESULTS}

A total of 1,378 papers were recovered for the period of 1988 to 2017, 182 of which dealt with insect galls in Brazil (Supplementary Material 1). The number of publications was found to have increased over the last 30 years $(r=0.82, p<0.001)$, and especially in the last decade (Fig. 1a). A significant increase in the diversity of journals that published on the subject was also found ( $r=0.90, p<0.05$, Fig. 1b). The publications came from 67 different journals, with the ten most important having published $48.35 \%$ of all the papers (Fig. 2). The top three journals, Revista Brasileira de Entomologia (24 papers),
Biota Neotropica (17) and Brazilian Journal of Biology (11), represented $28.57 \%$ of all the publications.

The compiled papers comprise a variety of different topics (Fig. 3a). The most common topic was ecology (94 papers), followed by inventory (29) and taxonomy (27), which together represented $82.41 \%$ of all the publications. The topics of the remaining papers were anatomy (15), review (9), agriculture (7) and genetics (2). Among the subtopics of ecology (Fig. 3b), there were papers on community ecology (47), population ecology (46) and biogeography (2). The top ten most cited papers of the 182 compiled studies are presented in Table 1, among which Fernandes \& Price (1988) and Fernandes \& Price (1992) stand out. The average number of total citations per paper was 16.05 ( \pm 27.66). There were no differences among papers on different topics in the average number of total citations $\left(F_{(7,174)}=1.39 ; p=0.21\right)$, but as expected older papers were cited more than more recent papers $\left(r^{2}=0.43 ; p<0.001\right)$. Considering the yearly rate of citation, $60.98 \%$ of the papers had less than two citations per year and $36.81 \%$ had less than one citation per year.

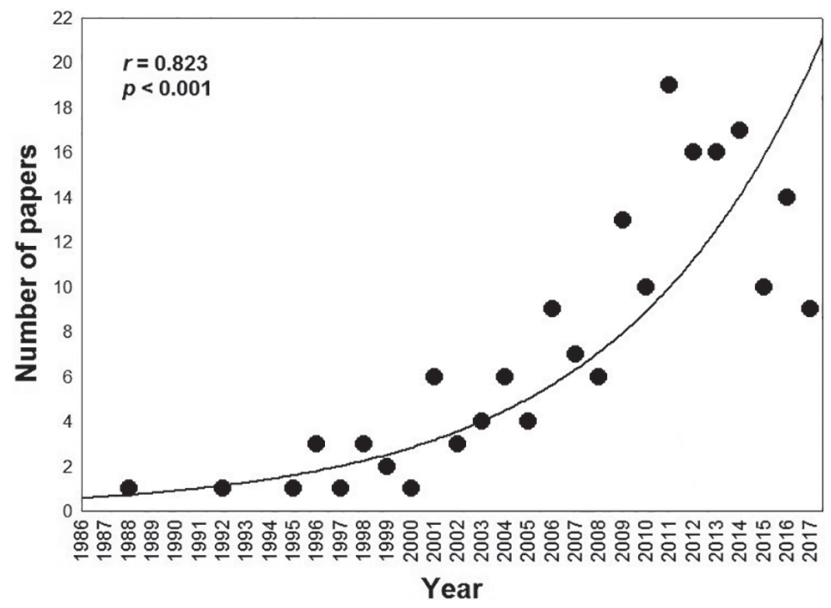

Figure 1. Historical trends (1988-2017) in publications on insect galls in Brazil (from CAPES database): (a) number of publications per year; and (b) diversity indexes of journals that published on the subject.

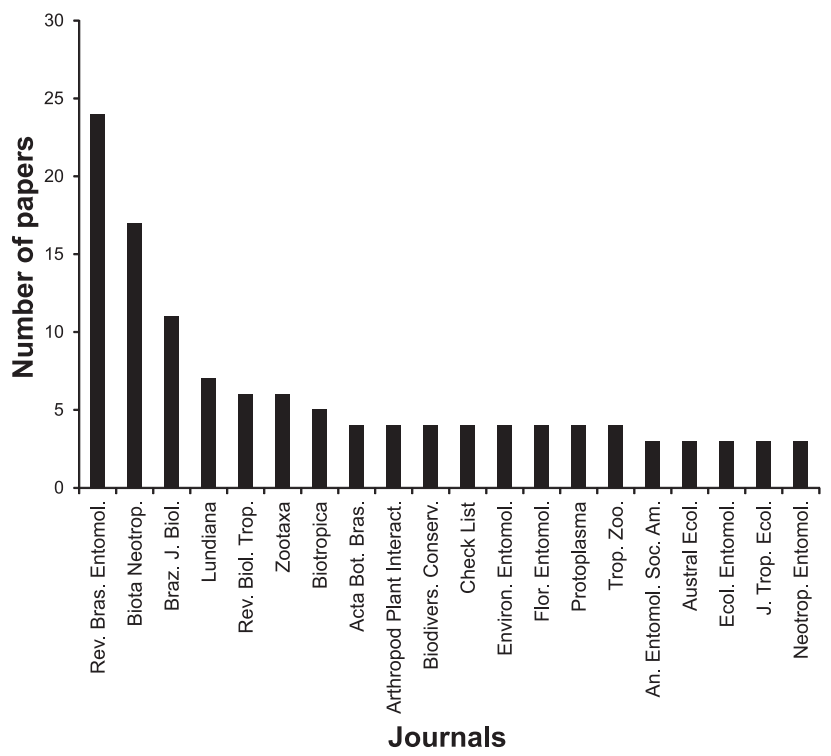

Figure 2. Main journals that published on insect galls in Brazil (from CAPES database). 
Table 1. The most frequently cited papers about insect galls in Brazil published from 1988 to 2017 (from CAPES database).

\begin{tabular}{|c|c|c|c|}
\hline Journal & Title & Authors & Citations* \\
\hline Oecologia & Biogeographical gradients in galling species richness - Tests of hypotheses & Fernandes \& Price (1988) & 190 \\
\hline Oecologia & $\begin{array}{l}\text { The adaptive significance of insect gall distribution: survivorship of species in xeric and } \\
\text { mesic habitats }\end{array}$ & Fernandes \& Price (1992) & 173 \\
\hline Journal of Biogeography & Global patterns in local number of insect galling species & Price et al. (1998) & 157 \\
\hline Functional Ecology & $\begin{array}{l}\text { The ecological function of extrafloral nectaries: Herbivore deterrence by visiting ants and } \\
\text { reproductive output in Caryocar brasiliense (Caryocaraceae) }\end{array}$ & Oliveira (1997) & 134 \\
\hline Biodiversity and Conservation & $\begin{array}{l}\text { Biodiversity of galling insects: Historical, community and habitat effects in four neotropical } \\
\text { savannas }\end{array}$ & Gonçalves-Alvim \& Fernandes (2001) & 92 \\
\hline Annals of the Entomological Society of America & How Many Species of Gall-Inducing Insects Are There on Earth, and Where Are They? & Espírito-Santo \& Fernandes (2007) & 91 \\
\hline Revista Brasileira de Entomologia & Are gall midge species (Diptera, Cecidomyiidae) host-plant specialists? & Carneiro et al. (2009) & 73 \\
\hline Ecological Entomology & $\begin{array}{l}\text { The occurrence and effectiveness of hypersensitive reaction against galling herbivores } \\
\text { across host taxa }\end{array}$ & Fernandes \& Negreiros (2008) & 64 \\
\hline Tropical Zoology & Galling insects on neotropical species of Baccharis (Asteraceae) & Fernandes et al. (1996) & 61 \\
\hline Brazilian Journal of Biology & Insect galls from Serra de São José (Tiradentes, MG, Brazil) & Maia \& Fernandes (2004) & 60 \\
\hline
\end{tabular}

* Number of citations in the SCOPUS database at 20/02/2018.

Forty-eight papers were inventories (Supplementary Material 2). Most of the insect gall inventories were located in Southeast Brazil (29 papers), followed by the Central-West and Northeast regions, with eight papers each (Fig. 4a). The North and South regions were the least studied, with two and one papers, respectively. Inventories of insect galls in Brazil were performed in 13 of the 27 Brazilian states (including the Federal District) (Fig. 5a), although the states of origin of most of the first authors represented only eight states, and were usually in Southeast Brazil (Fig. 5b). Among Brazilian states, Minas Gerais led in number of papers (16), followed by Rio de Janeiro (9) and Goiás (6) (Fig. 4b).

\section{DISCUSSION}

The results showed a significant increase in the number of papers published on insect galls in Brazil over the past 30 years, and especially over the last decade (2008-2017). The growing number of publications on this topic follows a global trend of exponential growth in the number of scientific publications over recent decades (Nabout et al., 2012; Nabout et al., 2015; Vaz et al., 2015). Scientometric analyses have also shown a significant increase in zoological scientific production, as has been demonstrated for mammalogy (Brito et al., 2009), carcinology (Nabout et al., 2010) and dipterology (Santos et al., 2017). Furthermore, recent scientometric studies have shown substantial growth in the scientific production of Latin American (e.g., Garcia et al., 2012), which was also observed for publications on insect galls, mainly due to the large contribution of Brazilian studies (Grandez-Rios et al., 2015).

A large number of scientific journals (67) published papers about Brazilian insect galls, but the three most important in terms of number of publications were Brazilian journals (i.e., Revista Brasileira de Entomologia, Biota Neotropica and Brazilian Journal of Biology). On the other hand, the ten most cited papers on the subject were almost all published in international journals (such as Oecologia, Journal of Biogeography and Functional Ecology). These results indicate a great degree of region- alism in the scientific production on insect galls in Brazil, since most of papers were published in regional journals (frequently in Portuguese) usually with low impact factors. Consequently, the number of citations per study and per year is generally low, which is relatively common for publications of Latin American authors (Nabout et al., 2015). An increase in the diversity of journals that publish on the subject was also found, which indicates that over the last few years a greater variety of aspects of insect gall diversity has been studied in Brazil.

Considering the topics that studies on insect galls in Brazil have focused on, approximately $50 \%$ of the publications were classified under ecology, i.e., investigations on the biology of galling species or the tests of ecological hypothesis. For example, Fernandes \& Price (1988), the most cited paper about insect galls in Brazil, tested several ecological hypotheses with emphasis on the hypotheses of hygrothermal stress and plant species richness, which remain the most frequently tested hypotheses in such studies. Two other important topics of insect gall studies in Brazil were inventory and taxonomy. Inventories represented $15.9 \%$ of the compiled papers and focused on the occurrence and morphological characterization of insect galls of different Brazilian sites. Inventory papers are important for describing insect gall diversity at different sites and provide information necessary for the development of other types of studies. Taxonomic studies, in turn, represented $14.8 \%$ of all the publications. Based on previous studies that estimated the potential number of galling species from Brazil as being much higher than the number of described species (Espírito-Santo \& Fernandes, 2007; Araújo et al., 2014; Grandez-Rios et al., 2015), taxonomic studies are very important for describing gall-inducer diversity, particularly of Cecidomyiidae, the most important gall-inducing insect group in the Neotropical region (Gagné, 1994).

Regarding the distribution of insect gall inventories among the geographical regions of Brazil, it is clear that there is a significant bias for studies in Southeast Brazil, which represents $60.4 \%$ of the publications (see Figs. 4 and 5). A similar pattern was also found for the states of origin of the first author, which are also concen- 
trated in Southeast Brazil. These biases are due to the states of Minas Gerais and Rio de Janeiro, which have historically been the most important Brazilian research centers (both in article publishing and in staff training) re-
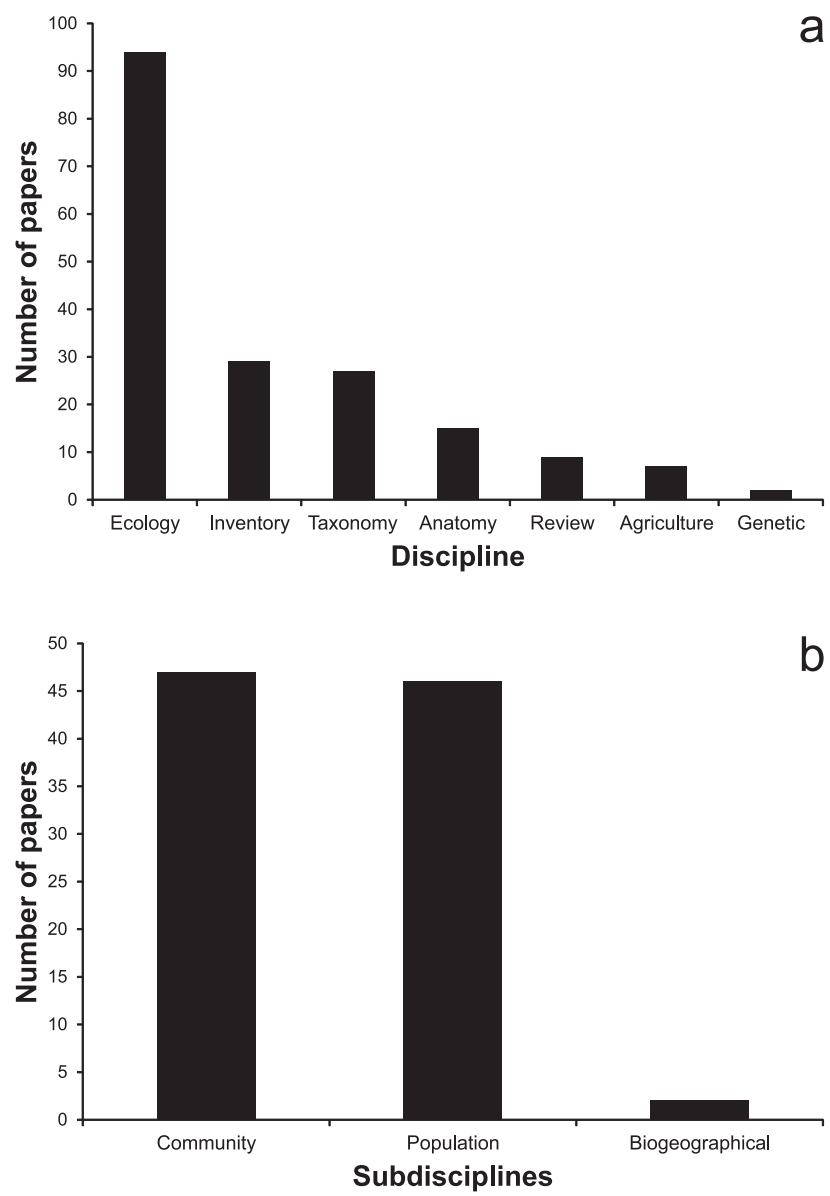

Figure 3. Number of publications about insect galls in Brazil (from CAPES database): (a) by topics (knowledge areas); and (b) by subtopics of ecology.

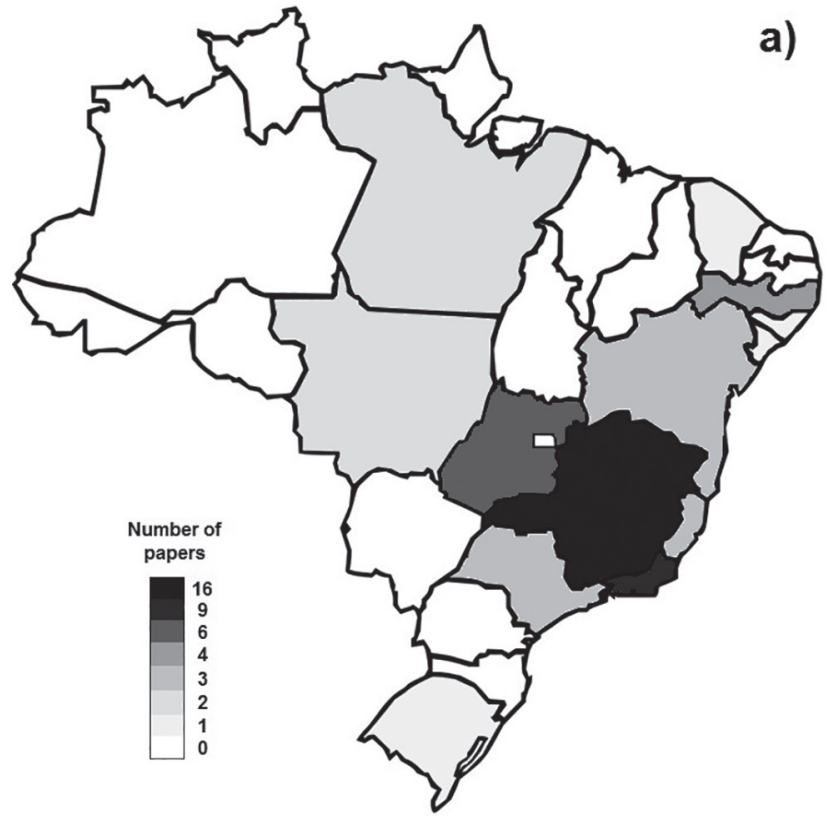

garding galls and galling insects, in particular the laboratories of G.W. Fernandes (Universidade Federal de Minas Gerais) and V.C. Maia (Museu Nacional, Universidade Federal do Rio de Janeiro), respectively. The former re-
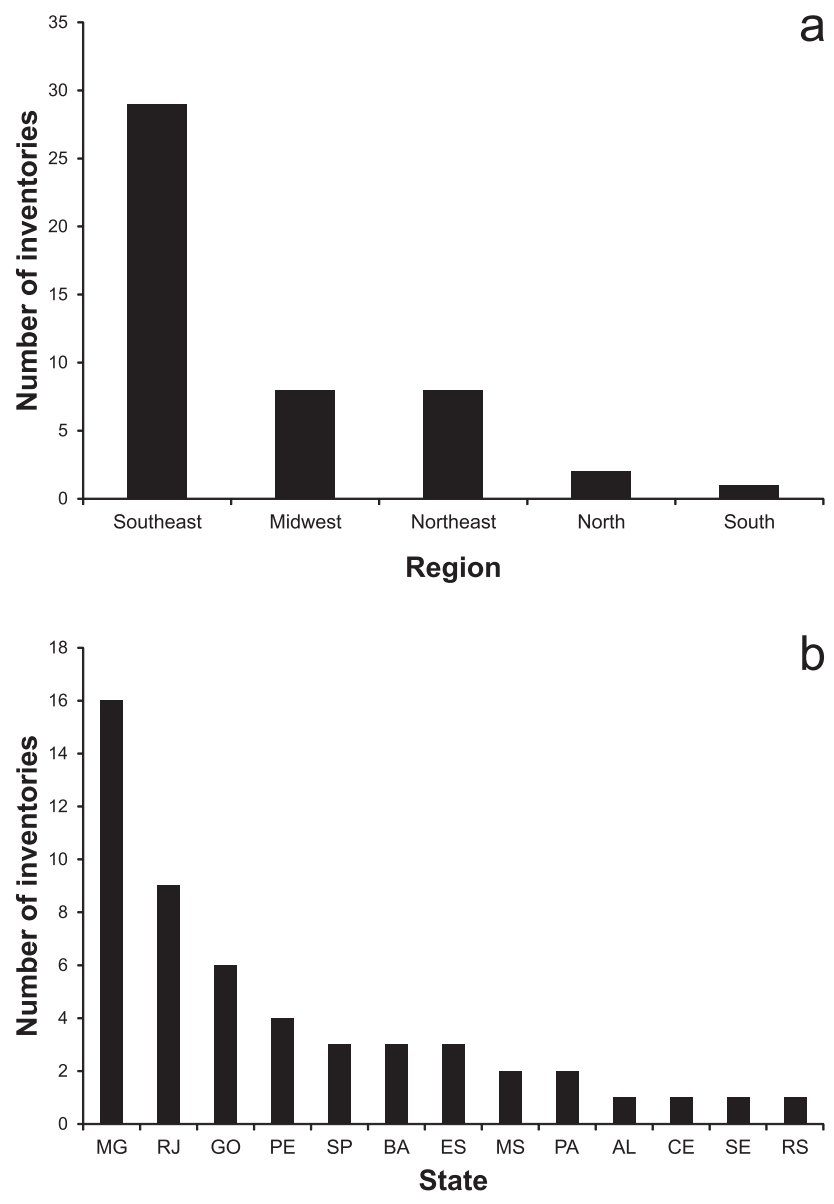

Figure 4. Number of inventories of insect galls in Brazil (CAPES and additional databases): (a) number of publications for Brazilian regions; and (b) number of publications for Brazilian states.

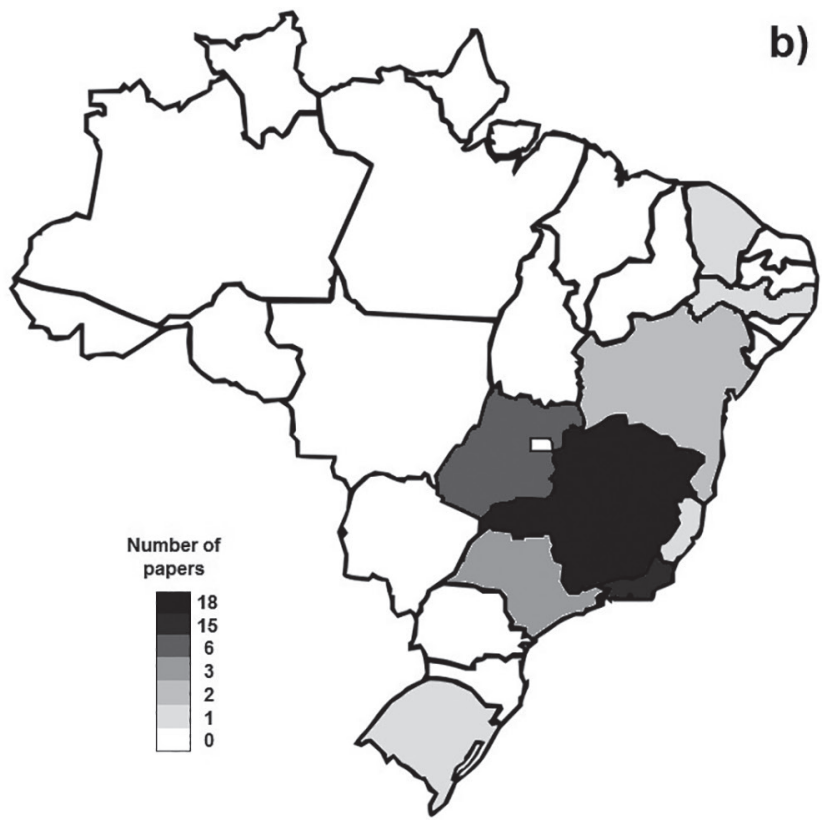

Figure 5. Geographic distribution of insect gall inventories among Brazilian states (from CAPES and additional databases): (a) the distribution of study area locations; and (b) distribution of the state of origin of the first author. 
search center has been dedicated to ecological research over the past three decades, while the latter has focused on taxonomic studies and faunistic inventories since the 1990s. Despite the increasing number of insect gall inventories in Brazil, the results show that there have been no papers published on the occurrence of insect galls in $51.8 \%$ of the states of Brazil. This result can be attributed to the lack of professionals in this area of study in most Brazilian states, which may indicate a problem in the training of scientists in Brazil, which tends to be concentrated in the Southeast region of the country.

\section{CONCLUSIONS}

The present study documents an increase in scientific production regarding insect galls in Brazil. Some well-studied topics, especially ecology, inventory and taxonomy, have contributed to the description and elucidation of patterns of the diversity of these insects in the Neotropical region (Fernandes \& Santos, 2014). On the other hand, there is great geographical bias among insect gall studies in Brazil, with most of the data acquired, and researchers involved, being concentrated in the Southeast region of the country. This spatial bias, along with estimates that suggest an enormous diversity of galling insects in Brazil (Espírito-Santo \& Fernandes, 2007; Grandez-Rios et al., 2015), make it clear that much remains to be done with regard to galls and galling insects in Brazil. A future challenge for researchers conducting studies about Brazilian insect galls is to increase the rate of publication in international journals with higher impact factors and, consequently, increase the average number of citations per study.

\section{ACKNOWLEDGEMENTS}

The author would like to thank Jean Carlos Santos, Charles Morphy D. Santos and one anonymous reviewer for suggestions on the manuscript and Erik Wild for English revision. This work was prepared as a presentation in the "IV Simpósio Brasileiro Sobre Galhas e Galhadores" of the "XXXII Congresso Brasileiro de Zoologia".

\section{REFERENCES}

Alcântara, J.A.; Souza, E.B. \& Braga, P.E.T. 2017. Ocorrência e caracterização de galhas em duas áreas do noroeste do Ceará, Brasil. Natureza On-Line, 15(1): 33-40.

Almada, E.D. \& Fernandes, G.W.A. 2011. Insetos indutores de galhas em florestas de terra firme e em reflorestamentos com espécies nativas na Amazônia Oriental, Pará, Brasil. Boletim do Museu Paraense Emílio Goeldi Ciências Naturais, 6(2): 163-196.

Araújo, W.S.; Santos, B.B. \& Gomes-Klein, V.L. 2011. Insect galls from Serra dos Pireneus, G0, Brazil. Biota Neotropica, 11(2): 357-365.

Araújo, W.S.; Santos, B.B.; Guilherme, F.A.G. \& Scareli-Santos, C. 2014. Galling insects in the Brazilian Cerrado: ecological patterns and perspectives. In: Fernandes, G.W. \& Santos, J.C. Eds.). Neotropical insect Galls. New York, Springer. p. 257-272
Bergamini, B.A.R.; Bergamini, L.L.; Santos, B.B. \& Araújo, W.S. 2017. Occurrence and characterization of insect galls in the Floresta Nacional de Silvânia, Brazil. Papéis Avulsos de Zoologia, 57(32): 413-431.

Borges, P.P.; Andrade Oliveira, K.A.F.; Machado, K.B.; Vaz, Ú.L., Cunha, H.F. \& Nabout, J.C. 2015. Trends and gaps of the scientific literature on the Cerrado biome: A scientometric analysis. Neotropical Biology and Conservation, 10(1): 2-8.

Bregonci, J.D.M.; Polycarpo, P.V. \& Maia, V.C. 2010. Insect galls of the Parque Estadual Paulo César Vinha (Guarapari, ES, Brazil). Biota Neotropica, 10(1): 265-274.

Brito, D.; Oliveira, L.C.;Oprea, M. \& Mello, M.A.R. 2009. An overview of Brazilian mammalogy: trends, biases and future directions. Zoologia, 26(1): 67-73.

Carneiro, M.A.A.; Branco, C.S.; Braga, C.E.; Almada, E.D.; Costa, M.; Maia, V.C. \& Fernandes, G.W. 2009. Are gall midge species (Diptera, Cecidomyiidae) host-plant specialists? Revista Brasileira de Entomologia, 53(3): 365-378.

Carvalho-Fernandes, S.P.; Almeida-Cortez, J.S.D. \& Ferreira, A.L.N. 2012. The insect gall richness in preserved and anthropic areas of caatinga. Revista Árvore, 36(2): 269-277.

Carvalho-Fernandes, S.P.; Ascendino, S.; Maia, V.C. \& Couri, M.S. 2016. Diversity of insect galls associated with coastal shrub vegetation in Rio de Janeiro, Brazil. Anais da Academia Brasileira de Ciências, 88(3): 1407-1418.

Carvalho-Fernandes, S.P.; Castelo-Branco, B.P.; Albuquerque, F.A.; Brito-Ramos, A.B.; Ferreira, A.L.N.; Braga, D.V.V. \& Almeida-Cortez, J.S. 2009. Galhas entomógenas em um fragmento urbano de Mata Atlântica no centro de endemismo de Pernambuco. Revista Brasileira de Biociências, 7(3):240-244.

Coelho, M.S.; Almada, E.D.; Fernandes, G.W.; Carneiro, M.A.A.; Santos, R.M.D.; Quintino, A.V. \& Sanchez-Azofeifa, A. 2009. Gall inducing arthropods from a seasonally dry tropical forest in Serra do Cipó, Brazil. Revista Brasileira de Entomologia, 53(3): 404-414.

Coelho, M.S.; Carneiro, M.A.A.; Branco, C.; Borges, R.A.X. \& Fernandes, G.W. 2013. Gall-inducing insects from Campos de Altitude, Brazil. Biota Neotropica, 13(4): 139-151.

Costa, E.C.; Carvalho-Fernandes, S.P. \& Santos-Silva, J. 2014. Galhas de insetos em uma área de transição caatinga-cerrado no Nordeste do Brasil. Sitientibus, Série Ciências Biológicas, 14(1): 1-9.

Drew, C.H.; Pettibone, K.G.; Finch 3rd, F.0.; Giles, D. \& Jordan, P. 2016. Automated research impact assessment: a new bibliometrics approach. Scientometrics, 106(3): 987-1005.

Espírito-Santo, M.M. \& Fernandes, G.W. 2007. How many species of gallinducing insects are there on earth, and where are they? Annals of the Entomological Society of America, 100(2): 95-99.

Fernandes, G.W. 1998. Hypersensitivity as a phenotypic basis of plant induced resistance against a galling insect (Diptera: Cecidomyiidae). Environmental Entomology, 27(2): 260-267.

Fernandes, G.W. \& Negreiros, D. 2006. A comunidade de insetos galhadores da RPPN fazenda bulcão, Aimorés, Minas Gerais, Brasil. Lundiana, 7(2): 111-120.

Fernandes, G.W. \& Negreiros, D. 2008. The occurrence and effectiveness of hypersensitive reaction against galling herbivores across host taxa. Ecological Entomology, 26(1): 46-55.

Fernandes, G.W. \& Price, P.W. 1988. Biogeographical gradients in galling species richness. Oecologia, 76(2): 161-167.

Fernandes, G.W. \& Price, P.W. 1992. The adaptive significance of insect gall distribution: survivorship of species in xeric and mesic habitats. Oecologia, 90(1): 14-20.

Fernandes, G.W. \& Santos, J.C. (Eds.). 2014. Neotropical insect galls (Vol. 550). Dordrecht, Springer. $550 \mathrm{p}$.

Fernandes, G.W.; Araújo, R.C.; Araújo, S.C.; Lombardi, J.A.; Silva De Paula, A.; Júnior, R.L. \& Cornelissen, T.G. 1997. Insect galls from savanna and rocky fields of the Jequitinhonha Valley, Minas Gerais, Brazil. Naturalia, 22(1): 221-244. 
Fernandes, G.W.; Carneiro, M.A.A.; Lara, A.C.F.; Allain, L.R.; Andrade, G.I.; Julião, G.R.; Reis, T.R. \& Silva, I.M. 1996. Galling insects on neotropical species of Baccharis (Asteraceae). Tropical Zoology, 9(2): 315-332.

Fernandes, G.W.; Julião, G.R.; Araújo, R.C.; Araújo, S.C.; Lombardi, J.A.; Negreiros, D. \& Carneiro, M.A.A. 2001. Distribution and morphology of insect galls of the Rio Doce Valley, Brazil. Naturalia, 26(1): 211-244.

Fernandes, G.W.A.; Tameirão-Neto, E. \& Martins, R.P. 1988. Ocorrência e caracterização de galhas entomógenas na vegetação do campus Pampulha da Universidade Federal de Minas Gerais. Revista Brasileira de Zoologia, 5(1): 11-29.

Gagné, R. 1994. The Gall Midges of the Neotropical Region. Ithaca, Cornell University Press. $360 \mathrm{p}$.

Garcia, C.R.S.; Parodi, A.J. \& Oliva, G. 2012. Growing Latin American science. Science, 338(6111): 1127.

Gonçalves-Alvim, S.J. \& Fernandes, G.W. 2001. Biodiversity of galling insects: historical, community and habitat effects in four neotropical savannas. Biodiversity \& Conservation, 10(1): 79-98.

Grandez-Rios, J.M.; García-Villacorta, R.; Cuevas-Reyes, P. \& Araújo, W.S. 2015. Insectos inductores de agallas en América Latina: ecología, importancia y nuevas perspectivas. Revista de Biologia Neotropical, 12(2): 92-103.

Julião, G.R.; Amaral, M. \& Fernandes, G.W. 2002. Galhas de insetos e suas plantas hospedeiras no Pantanal sul-mato-grossense. Naturalia, 27(1): 47-74.

Luz, R.G.; Fernandes, G.W.; Silva, J.0.; Neves, F.S. \& Fagundes, M. 2012. Galhas de insetos em habitats xérico e mésico em região de transição Cerrado-Caatinga no norte de Minas Gerais, Brasil. Neotropical Biology \& Conservation, 7(3): 171-187.

Maia, V. \& Oliveira, J. 2010. Galhas de insetos da Reserva Biológica Estadual da Praia do Sul (Ilha Grande, Angra dos Reis, RJ). Biota Neotropica, 10(4): 227-238.

Maia, V.C. 2001. The gall midges (Diptera, Cecidomyiidae) from three restingas of Rio de Janeiro State, Brazil. Revista Brasileira de Zoologia, 18(2):583-629.

Maia, V.C. 2005. Catálogo dos Cecidomyiidae (Diptera) do estado do Rio de Janeiro. Biota Neotropica, 5(2): 189-203.

Maia, V.C. 2011. Characterization of insect galls, gall makers, and associated fauna of Platô Bacaba (Porto de Trombetas, Pará, Brazil). Biota Neotropica, 11(4): 37-53.

Maia, V.C. 2013. Insect galls of São Tomé das Letras (MG, Brazil). Biota Neotropica, 13(4): 164-189.

Maia, V.C. 2014. Insect galls of Itamonte (Minas Gerais, Brazil): characterization and occurrence. Biota Neotropica, 14(1): e20133839.

Maia, V.C. \& Carvalho-Fernandes, S.P. 2016. Insect galls of a protected remnant of the Atlantic Forest tableland from Rio de Janeiro State (Brazil). Revista Brasileira de Entomologia, 60(1): 40-56.

Maia, V.C. \& Fernandes, G.W. 2004. Insect galls from Serra de São José (Tiradentes, MG, Brazil). Brazilian Journal of Biology, 6(3a): 423-445.

Maia, V.C. \& Silva, L.0. 2016. Insect galls of Restinga de Marambaia (Barra de Guaratiba, Rio de Janeiro, RJ). Brazilian Journal of Biology, 76(3): 787-795.

Maia, V.C. \& Souza, M.C. 2013. Insect galls of the xeric vegetation of llha do Cabo Frio (Arraial do Cabo, RJ, Brazil). Biota Neotropica, 13(3): 278-288.

Maia, V.C.; Cardoso, L.J.T. \& Braga, J.M.A. 2014. Insect galls from Atlantic Forest areas of Santa Teresa, Espírito Santo, Brazil: characterization and occurrence. Boletim do Museu de Biologia Mello Leitão, 33(1): 47-129.

Maia, V.C.; Galvão-Magenta, M.A. \& Martins, E.S. 2008. Ocorrência e caracterização de galhas de insetos em áreas de restinga de Bertioga (São Paulo, Brasil). Biota Neotropica, 8(1): 167-197.

Malves, K. \& Frieiro-Costa, F.A. 2012. List of plants with galls induced by insects from the UNILAVRAS/Boqueirão Biological Reserve, Ingaí, State of Minas Gerais, Brazil. Check List, 8(3): 426-431.

Moreira, G.R.P. 2006. Galhas entomógenas no Brasil: oportunidade de estudo sobre interação inseto-planta. In: Mariath, J.E. \& Santos, R.P. (Orgs.). Os avanços da botânica no inicio do século XXI do $57^{\circ}$ Congresso Nacional de Botânica. Porto Alegre, Sociedade de Botânica do Brasil. p. 532-537.

Moreira, R.G.; Fernandes, G.W.; Almada, E.D. \& Santos, J.C. 2007. Galling insects as bioindicators of land restoration in an area of Brazilian Atlantic Forest. Lundiana, 8(2): 107-112.

Nabout, J.C.; Bini, L.M. \& Diniz-Filho, J.A. 2010. Global literature of fiddler crabs, genus Uca (Decapoda, Ocypodidae): trends and future directions. Iheringia Série Zoologia, 100(4): 463-468.

Nabout, J.C.; Carneiro, F.M.; Borges, P.P.; Machado, K.B. \& Huszar, V.L.M. 2015. Brazilian scientific production on phytoplankton studies: national determinants and international comparisons. Brazilian Journal of Biology, 75(1): 216-223.

Nabout, J.C.; Carvalho, P.; Prado, M.U.; Borges, P.P.; Machado, K.B.; Haddad, K.B.; Michelan, T.S.; Cunha, H.F. \& Soares, T.N. 2012. Trends and biases in global climate change literature. Natureza \& Conservação, 10(1): 45-51.

Oliveira, J.D. \& Maia, V.C. 2005. Ocorrência e caracterização de galhas de insetos na restinga de Grumari (Rio de Janeiro, RJ, Brasil). Arquivos do Museu Nacional, 63(4): 669-675.

Oliveira, P.S. 1997. The ecological function of extrafloral nectaries: herbivore deterrence by visiting ants and reproductive output in Caryocar brasiliense (Caryocaraceae). Functional Ecology, 11(3): 323-330.

Price, P.W.; Fernandes, G.W.; Lara, A.C.F.; Brawn, J.; Barrios, H.; Wright, M.G.; Ribeiro, S.P. \& Rothcliff, N. 1998. Global patterns in local number of insect galling species. Journal of Biogeography, 25(3): 581-591.

Rodrigues, A.R.; Maia, V.C. \& Couri, M.S. 2014. Insect galls of restinga areas of llha da Marambaia, Rio de Janeiro, Brazil. Revista Brasileira de Entomologia, 58(2): 173-197.

Saito, V.S. \& Urso-Guimarães, M.V. 2012. Characterization of galls, insect galls and associated fauna of Ecological Station of Jataí (Luiz Antônio, SP). Biota Neotropica, 12(3): 99-107.

Santos, B.B.; Ferreira, H.D. \& de Araújo, W.S. 2010. Ocorrência e caracterização de galhas entomógenas em uma área de floresta estacional semidecídua em Goiânia, Goiás, Brasil. Acta Botânica Brasilica, 24(1): 243-249.

Santos, B.B.; Ribeiro, B.A.; Silva, T.M. \& Araújo, W. 2012. Galhas de insetos em uma área de cerrado sentido restrito na região semi-urbana de Caldas Novas (Goiás, Brasil). Revista Brasileira de Biociências, 10(4): 439-445.

Santos, D.; Sampronha, S. \& Santos, C.H.D. 2017. Advances on dipterology in the $21^{\text {st }}$ century and extinction rates. Papéis Avulsos de Zoologia, 57(33): 433-444.

Santos, J.C.; Almeida-Cortez, J.S. \& Fernandes, G.W. 2011. Diversity of gallinducing insects in the high altitude wetland forests in Pernambuco, Northeastern Brazil. Brazilian Journal of Biology, 71(1): 47-56.

Silva, T.M.; Araújo, W.S. \& Santos, B.B. 2015. Ocorrência e caracterização de galhas de insetos em um fragmento de mata semicaducifólia do Campus Samambaia, Goiânia, G0, Brasil. Revista de Biologia Neotropical, 12(1): 26-38.

Toma, T.S.P. \& Mendonça Jr., M.S. 2013. Gall-inducing insects of an Araucaria Forest in southern Brazil. Revista Brasileira de Entomologia, 57(2): 225-233.

Urso-Guimarães, M.V. \& Scareli-Santos, C. 2006. Galls and gall makers in plants from the Pé-de-Gigante Cerrado reserve, Santa Rita do Passa Quatro, SP, Brazil. Brazilian Journal of Biology, 66(1B): 357-369.

Urso-Guimarães, M.V.; Castello, A.C.D.; Kataoka, E.Y. \& Koch, I. 2017. Characterization of entomogen galls from Mato Grosso do Sul, Brazil. Revista Brasileira de Entomologia, 61(1): 25-42.

Urso-Guimarães, M.V.; Scareli-Santos, C. \& Bonifácio-Silva, A.C. 2003. Occurrence and characterization of entomogen galls in plants from natural vegetation areas in Delfinópolis, MG, Brazil. Brazilian Journal of Biology, 63(4): 705-715.

Vaz, U.L.; Cunha, H.F. \& Nabout, J.C. 2015. Trends and biases in global scientific literature about ecological niche models. Brazilian Journal of Biology, 75(4): S17-S24. 


\section{SUPPLEMENTARY MATERIAL 1}

List of papers about insect galls and galling species in Brazil published in peer-reviewed journals between 1988 and 2017 compiled from papers indexed in the platform "Portal de Periódicos Capes" (www.periodicos.capes.gov.br).

\begin{tabular}{|c|c|c|c|}
\hline $\mathbf{N}$ & Title & Year & Journal \\
\hline 1 & Biogeographical gradients in galling species richness - Tests of hypotheses & 1988 & 0ecologia \\
\hline 2 & Adaptive significance of insect gall distribution: survivorship of species in xeric and mesic habitats & 1992 & 0ecologia \\
\hline 3 & Utilization of Apion sp. (Coleoptera apionidae) galls by an ant community in southeastern brazil & 1995 & Tropical Zoology \\
\hline 4 & Fire effects on a Palicourea rigida (rubiaceae) gall midge: A test of the plant vigor hypothesis & 1996 & Biotropica \\
\hline 5 & Galling insects on neotropical species of Baccharis (Asteraceae) & 1996 & Tropical Zoology \\
\hline 6 & The highest diversity of galling insects: Serra do Cipó, Brazil & 1996 & Biodiversity Letters \\
\hline 7 & $\begin{array}{l}\text { The ecological function of extrafloral nectaries: Herbivore deterrence by visiting ants and reproductive output in Caryocar } \\
\text { brasiliense (Caryocaraceae) }\end{array}$ & 1997 & Functional Ecology \\
\hline 8 & Global patterns in local number of insect galling species & 1998 & Journal of Biogeography \\
\hline 9 & Hypersensitivity as a Phenotypic Basis of Plant Induced Resistance Against a Galling Insect (Diptera: Cecidomyiidae) & 1998 & Environmental Entomology \\
\hline 10 & $\begin{array}{l}\text { Natural history of a gall-inducing weevil Collabismus clitellae (Coleoptera: Curculionidae) and some effects on its host } \\
\text { plant Solanum lycocarpum (Solanaceae) in southeastern Brazil }\end{array}$ & 1998 & Annals of the Entomological Society of America \\
\hline 11 & Abundance and impact of a Lepidopteran gall on Macairea radula (Melastomataceae) in the Neotropics & 1999 & International Journal of Ecology and Environmental Sciences \\
\hline 12 & The interplay between plant traits and herbivore attack: A study of a stem galling midge in the neotropics & 1999 & Ecological Entomology \\
\hline 13 & Distance-limited recolonization of burned cerrado by leaf-miners and gallers in central Brazil & 2000 & Environmental Entomology \\
\hline 14 & Biodiversity of galling insects: Historical, community and habitat effects in four neotropical savannas & 2001 & Biodiversity and Conservation \\
\hline 15 & Galling insect diversity patterns: the resource synchronisation hypothesis & 2001 & Oikos \\
\hline 16 & Host plant response and phenotypic plasticity of a galling weevil (Collabismus clitellae: Curculionidae) & 2001 & Austral Ecology \\
\hline 17 & Leaf gall abundance on Avicennia germinans (Avicenniaceae) along an interstitial salinity gradient & 2001 & Biotropica \\
\hline 18 & The occurrence and effectiveness of hypersensitive reaction against galling herbivores across host taxa & 2001 & Ecological Entomology \\
\hline 19 & Vigour of a dioecious shrub and attack by a galling herbivore & 2001 & Ecological Entomology \\
\hline 20 & Host plant effects on the development and survivorship of the galling insect Neopelma baccharidis (Homoptera: Psyllidae) & 2002 & Austral Ecology \\
\hline 21 & Influence of host-plant sex and habitat on survivorship of insect galls within the geographical range of the host-plant & 2002 & Tropical Zoology \\
\hline 22 & Tests of hypotheses on patterns of gall distribution along an altitudinal gradient & 2002 & Tropical Zoology \\
\hline 23 & $\begin{array}{l}\text { Complex interactions envolving a gall midge Myrciamyia maricaensis Maia (Diptera, Cecidomyiidae), phytophagous } \\
\text { modifiers and parasitoids }\end{array}$ & 2003 & Revista Brasileira de Zoologia \\
\hline 24 & Galling insects (Diptera: Cecidomyiidae) survive inundation during host plant flooding in Central Amazonia & 2003 & Biotropica \\
\hline 25 & Hypersensitivity of Fagus sy/vatica L. against leaf galling insects & 2003 & Trees \\
\hline 26 & Occurrence and characterization of entomogen galls in plants from natural vegetation areas in Delfinópolis, MG, Brazil & 2003 & Brazilian Journal of Biology \\
\hline 27 & $\begin{array}{l}\text { A key to genera to Eriococcidae (Hemiptera: Coccoidea) from the Neotropical region and a revision of Pseudotectococcus } \\
\text { Hempel (Eriococcidae), a gall inducing scale insect genus from Brazil, with a description of a new species }\end{array}$ & 2004 & Lundiana \\
\hline 28 & $\begin{array}{l}\text { Edge effect and species-area relationships in the gall-forming insect fauna of natural forest patches in the Brazilian } \\
\text { Pantanal }\end{array}$ & 2004 & Biodiversity and Conservation \\
\hline 29 & $\begin{array}{l}\text { Effects of genetic variability and habitat of Qualea parviflora (Vochysiaceae) on herbivory by free-feeding and gall- } \\
\text { forming insects }\end{array}$ & 2004 & Annals of Botany \\
\hline 30 & $\begin{array}{l}\text { Gall-inducing jumping plant-lice of the Neotropical genus Baccharopelma (Hemiptera, Psylloidea) associated with } \\
\text { Baccharis (Asteraceae) }\end{array}$ & 2004 & Journal of Natural History \\
\hline 31 & Insect galls from Serra de São José (Tiradentes, MG, Brazil) & 2004 & Brazilian Journal of Biology \\
\hline 32 & $\begin{array}{l}\text { Novas espécies de Prodecatoma (Hymenoptera, Eurytomidae) associadas a galhas em frutos de duas espécies de Psidium } \\
\text { L. (Myrtaceae), com comentários sobre Prodecatoma spermophaga Costa-Lima }\end{array}$ & 2004 & Revista Brasileira de Entomologia \\
\hline 33 & A new genus and species of gall midge (Diptera: Cecidomyiidae) associated with Waltheria indica L. (Sterculiaceae) & 2005 & Zootaxa \\
\hline 34 & Convergence in the variation of local and regional galling species richness & 2005 & Neotropical Entomology \\
\hline 35 & Insetos galhadores associados a duas espécies de plantas invasoras de áreas urbanas e peri-urbanas & 2005 & Revista Brasileira de Entomologia \\
\hline 36 & Two new species of Asphondyliini (Diptera: Cecidomyiidae) associated with Bauhinia brevipes (Fabaceae) in Brazil & 2005 & Zootaxa \\
\hline 37 & $\begin{array}{l}\text { Distribution and frequency of galls induced by Anisodiplosis waltheriae Maia (Diptera: Cecidomyiidae) on the invasive } \\
\text { plant Waltheria indica L. (Sterculiaceae) }\end{array}$ & 2006 & Neotropical Entomology \\
\hline 38 & Diversity of galling arthropods and host plants in a subtropical forest of Porto Alegre, southern Brazil & 2006 & Neotropical Entomology \\
\hline 39 & Effects of host plant architecture on colonization by galling insects & 2006 & Austral Ecology \\
\hline 40 & $\begin{array}{l}\text { Influence of Apion sp. (Brentidae, Apioninae) stem-galls on induced resistance and leaf area of Diospyros hispida } \\
\text { (Ebenaceae) }\end{array}$ & 2006 & Revista Brasileira de Entomologia \\
\hline 41 & Insect galls occurring in Miconia prasina (Melastomataceae) in remnants of Atlantic forest of northeastern Brazil & 2006 & Lundiana \\
\hline 42 & Insetos fitófagos associados ao murici da praia, Byrsonima sericea (Malpighiaceae), na Restinga de Jurubatiba (RJ) & 2006 & Revista Brasileira de Entomologia \\
\hline 43 & Processes driving ontogenetic succession of galls in a canopy tree & 2006 & Biotropica \\
\hline 44 & Sex-mediated herbivory by galling insects on Baccharis concinna (Asteraceae) & 2006 & Revista Brasileira de Entomologia \\
\hline 45 & A comunidade de insetos galhadores da RPPN Fazenda Bulcão, Aimorés, Minas Gerais, Brasil & 2006 & Lundiana \\
\hline
\end{tabular}




\begin{tabular}{|c|c|c|c|}
\hline $\mathbf{N}$ & Title & Year & Journal \\
\hline 46 & $\begin{array}{l}\text { Caracterização e distribuição espacial de galhas em Clusia nemorosa G. Mey (Clusiaceae) em uma área de Floresta } \\
\text { Atlântica, Igarassu, PE }\end{array}$ & 2007 & Lundiana \\
\hline 47 & $\begin{array}{l}\text { Ecology and impact of Allorhogas sp. (Hymenoptera: Braconidae) and Apion sp. (Coleoptera: Curculionoidea) on fruits of } \\
\text { Miconia calvescens DC (Melastomataceae) in Brazil }\end{array}$ & 2007 & Biological Control \\
\hline 48 & Effect of aib on quality and phytossanity of Caryocar brasiliense Camb (Caryocaraceae) air layering & 2007 & Revista Arvore \\
\hline 49 & Galling insects as bioindicators of land restoration in an area of Brazilian Atlantic forest & 2007 & Lundiana \\
\hline 50 & How Many Species of Gall-Inducing Insects Are There on Earth, and Where Are They? & 2007 & Annals of the Entomological Society of America \\
\hline 51 & Impact of a gall midge Parkiamyia paraensis (Diptera, Cecidomyiidae) on the Amazonian plant Parkia pendula (Fabaceae) & 2007 & Revista Brasileira de Entomologia \\
\hline 52 & Plant architecture and meristem dynamics as the mechanisms determining the diversity of gall-inducing insects & 2007 & 0ecologia \\
\hline 53 & $\begin{array}{l}\text { Asphondylia gochnatiae, a new species of gall midge (Diptera, Cecidomyiidae) associated with Gochnatia polymorpha } \\
\text { (Less.) Cabrera (Asteraceae) }\end{array}$ & 2008 & Zootaxa \\
\hline 54 & Ocorrência e caracterização de galhas de insetos em áreas de restinga de Bertioga (São Paulo, Brasil) & 2008 & Biota Neotropica \\
\hline 55 & $\begin{array}{l}\text { Phytotoxicity of the extracts of Lonchocarpus muehlbergianus Hassl. (Fabaceae) leaflets and galls on seed germination and } \\
\text { early development of lettuce }\end{array}$ & 2008 & Acta Botanica Brasilica \\
\hline 56 & Plant organ abscission and the green island effect caused by gallmidges (Cecidomyiidae) on tropical trees & 2008 & Arthropod-Plant Interactions \\
\hline 57 & Relationships between host plant architecture and gall abundance and survival & 2008 & Revista Brasileira de Entomologia \\
\hline 58 & $\begin{array}{l}\text { Species-specific changes in tissue morphogenesis induced by two arthropod leaf gallers in Lantana camara L. } \\
\text { (Verbenaceae) }\end{array}$ & 2008 & Australian Journal of Botany \\
\hline 59 & A new genus and species of gall midge (Diptera, Cecidomyiidae) associated with Myrcia retorta (Myrtaceae) & 2009 & Revista Brasileira de Entomologia \\
\hline 60 & Are gall midge species (Diptera, Cecidomyiidae) host-plant specialists? & 2009 & Revista Brasileira de Entomologia \\
\hline 61 & Asphondylia fructicola, a new species of Cecidomyiidae (Diptera) associated with Solanum sp. (Solanaceae) from Brazil & 2009 & Revista Brasileira de Entomologia \\
\hline 62 & $\begin{array}{l}\text { Efeitos da sazonalidade e do tamanho da planta hospedeira na abundância de galhas de Cecidomyiidae (Diptera) em Piper } \\
\text { arboreum (Piperaceae) }\end{array}$ & 2009 & Revista Brasileira de Entomologia \\
\hline 63 & Gall inducing arthropods from a seasonally dry tropical forest in Serra do Cipó, Brazil & 2009 & Revista Brasileira de Entomologia \\
\hline 64 & Insetos indutores de galhas da porção sul da Cadeia do Espinhaço, Minas Gerais, Brasil & 2009 & Revista Brasileira de Entomologia \\
\hline 65 & Gall midge attack intensity and host-plant response in a Neotropical coastal ecosystem & 2009 & Revista Brasileira de Entomologia \\
\hline 66 & Grape phylloxera in Brazil & 2009 & Acta Horticulturae \\
\hline 67 & $\begin{array}{l}\text { Influence of leaflet age in anatomy and possible adaptive values of the midrib gall of Copaifera langsdorffii (Fabaceae: } \\
\text { Caesalpinioideae) }\end{array}$ & 2009 & Revista de Biologia Tropical \\
\hline 68 & Intra-specific phenotypic variations in Lantana camara leaves affect host selection by the gall maker Aceria lantanae & 2009 & Biochemical Systematics and Ecology \\
\hline 69 & Complexidade estrutural e diversidade de insetos galhadores em Styrax pohlii Fritsch (Styracaceae) & 2009 & Bioscience Journal \\
\hline 70 & $\begin{array}{l}\text { Two new gall-inducing genera and species of Eriococcidae (Hemiptera) on Malvaceae and Anacardiaceae from the } \\
\text { Neotropics }\end{array}$ & 2009 & Lundiana \\
\hline 71 & Within tree distribution of a gall-inducing Eurytoma (Hymenoptera, Eurytomidae) on Caryocar brasiliense (Caryocaraceae) & 2009 & Revista Brasileira de Entomologia \\
\hline 72 & $\begin{array}{l}\text { Description of the female, pupa and gall of Pisphondylia brasiliensis Couri and Maia, } 1992 \text { (Diptera: Cecidomyiidae, } \\
\text { Schizomyiina) with new records }\end{array}$ & 2010 & Brazilian Journal of Biology \\
\hline 73 & $\begin{array}{l}\text { First record of galls in hog plum (Spondias mombim L.) panicles caused by Clinodiplosis (Diptera: Cecidomyiidae) and } \\
\text { evaluation of genotypes in the State of Piauí }\end{array}$ & 2010 & Revista Brasileira de Fruticultura \\
\hline 74 & Gall midges (Diptera, Cecidomyiidae) associated with Aldina heterophylla spr. ex Benth. (Fabaceae) from Brazil & 2010 & Biota Neotropica \\
\hline 75 & Gall-inducing insect species richness as indicators of forest age and Health & 2010 & Environmental Entomology \\
\hline 76 & Insect galls of the Parque Estadual Paulo César Vinha (Guarapari, ES, Brazil) [ & 2010 & Biota Neotropica \\
\hline 77 & $\begin{array}{l}\text { [0corrência e caracterização de galhas entomógenas em uma área de floresta estacional semidecídua em Goiânia, Goiás, } \\
\text { Brasil }\end{array}$ & 2010 & Acta Botanica Brasilica \\
\hline 78 & Pattern of attack of a galling insect reveals an unexpected preference-performance linkage on medium-sized resources & 2010 & Revista Brasileira de Entomologia \\
\hline 79 & Photosynthetic efficiency of Clusia arrudae leaf tissue with and without Cecidomyiidae galls & 2010 & Brazilian Journal of Biology \\
\hline 80 & Redifferentiation of leaflet tissues during midrib gall development in Copaifera langsdorffii (Fabaceae) & 2010 & South African Journal of Botany \\
\hline 81 & Two new species of Lopesia Rübsaamen (Diptera, Cecidomyiidae) from Brazil, with an identification key of species & 2010 & Biota Neotropica \\
\hline 82 & $\begin{array}{l}\text { A new genus and species of gall midge (Diptera, Cecidomyiidae) associated with Microgramma vacciniifolia (Langsd. \& } \\
\text { Fisch.) Copel. (Polypodiaceae) from Brazil }\end{array}$ & 2011 & Revista Brasileira de Entomologia \\
\hline 83 & $\begin{array}{l}\text { Abundance of gall-inducing insect species in sclerophyllous savanna: Understanding the importance of soil fertility using } \\
\text { an experimental approach }\end{array}$ & 2011 & Journal of Tropical Ecology \\
\hline 84 & $\begin{array}{l}\text { Burseramyia braziliensis, a new species of gall midge (Diptera, Cecidomyiidae, Asphondyliini) associated with Swartzia } \\
\text { langsdorffii Raddi (Fabaceae) }\end{array}$ & 2011 & Biota Neotropica \\
\hline 85 & $\begin{array}{l}\text { Calophya latiforceps, a new species of jumping plant lice (Hemiptera: Calophyidae) associated with Schinus terebinthifolius } \\
\text { (Anacardiaceae) in Brazil }\end{array}$ & 2011 & Florida Entomologist \\
\hline 86 & Can host plant richness be used as a surrogate for galling insect diversity? & 2011 & Tropical Conservation Science \\
\hline 87 & Characterization of insect galls, gall makers, and associated fauna of Platô Bacaba (Porto de Trombetas, Pará, Brazil) & 2011 & Biota Neotropica \\
\hline 88 & Cytological and histochemical gradients on two Copaifera langsdorffii Desf. (Fabaceae)-Cecidomyiidae gall systems & 2011 & Protoplasma \\
\hline 89 & $\begin{array}{l}\text { Differential female attack and larval performance of a galling cecidomyiid on the host, Astronium fraxinifolium } \\
\text { (Anacardiaceae), in contrasting habitats }\end{array}$ & 2011 & Entomological News \\
\hline 90 & Distribution of a leaf vein gall in Caryocar Brasiliense (Caryocaraceae) tree & 2011 & Revista Caatinga \\
\hline
\end{tabular}




\begin{tabular}{|c|c|c|c|}
\hline $\mathbf{N}$ & Title & Year & Journal \\
\hline 91 & Diversity of gall-inducing insects in the high altitude wetland forests in Pernambuco, Northeastern Brazil & 2011 & Brazilian Journal of Biology \\
\hline 92 & Diversity of galling insects in Styrax pohlii (Styracaceae): Edge effect and use as bioindicators & 2011 & Revista de Biologia Tropical \\
\hline 93 & Fire increases insect herbivory in a neotropical savanna & 2011 & Biotropica \\
\hline 94 & Herbivory, pathogens, and epiphylls in araucaria forest and ecologically-managed tree monocultures & 2011 & Forest Ecology and Management \\
\hline 95 & Insect galls from Serra dos Pireneus, G0, Brazil [Galhas de insetos da Serra dos Pireneus, G0, Brasil] & 2011 & Biota Neotropica \\
\hline 96 & $\begin{array}{l}\text { Insect herbivores associated with Baccharis dracunculifolia (Asteraceae): Responses of gall-forming and free-feeding } \\
\text { insects to latitudinal variation }\end{array}$ & 2011 & Revista de Biologia Tropical \\
\hline 97 & Richness of gall-inducing insects in the tropical dry forest (caatinga) of Pernambuco & 2011 & Revista Brasileira de Entomologia \\
\hline 98 & Size, age and composition: Characteristics of plant taxa as diversity predictors of gall-midges (Diptera: Cecidomyiidae) & 2011 & Revista de Biologia Tropical \\
\hline 99 & Spatial distribution of a spherical gall (Hymenoptera, Eulophidae) on Caryocar brasiliense (Caryocaraceae) & 2011 & Revista Brasileira de Entomologia \\
\hline 100 & $\begin{array}{l}\text { Two new species of gall midges (Diptera, Cecidomyiidae) associated with Erythroxylum ovalifolium Peyr. (Erythroxylaceae) } \\
\text { from the barra de Maricá restinga, Maricá, Rio de Janeiro, Brazil [ }\end{array}$ & 2011 & Brazilian Journal of Biology \\
\hline 101 & Characterization of galls, insect galls and associated fauna of Ecological Station of Jataí (Luiz Antônio, SP) & 2012 & Biota Neotropica \\
\hline 102 & Edge effect benefits galling insects in the Brazilian Amazon & 2012 & Biodiversity and Conservation \\
\hline 103 & Eugeniamyia dispar in Surinam cherry: Associated parasitoids, population dynamics and distribution of plant galls & 2012 & Revista Brasileira de Fruticultura \\
\hline 104 & Gall-inducing insects from Atlantic forest of Pernambuco, Northeastern Brazil & 2012 & Biota Neotropica \\
\hline 105 & Distribuição de insetos galhadores em diferentes formações vegetais e paisagens do cerrado brasileiro & 2012 & Bioscience Journal \\
\hline 106 & Herbivory among habitats on the Neotropical tree Cnidoscolus quercifolius Pohl. in a seasonally deciduous forest & 2012 & Brazilian Journal of Biology \\
\hline 107 & Galhas de insetos em habitats xérico e mésico em região de transição Cerrado-Caatinga no norte de Minas Gerais, Brasil & 2012 & Neotropical Biology and Conservation \\
\hline 108 & $\begin{array}{l}\text { List of plants with galls induced by insects from the UNILAVRAS/Boqueirão Biological Reserve, Ingaí, state of Minas Gerais, } \\
\text { Brazil }\end{array}$ & 2012 & Check List \\
\hline 109 & Mutualism from the inside: Coordinated development of plant and insect in an active pollinating fig wasp & 2012 & Arthropod-Plant Interactions \\
\hline 110 & Population ecology of the multivoltine Neotropical gall midge Eugeniamyia dispar (Diptera, Cecidomyiidae) & 2012 & Iheringia Série Zoologia \\
\hline 111 & $\begin{array}{l}\text { Population structure and genetic diversity analysis in Gynaikothrips uzeli (Zimerman, 1909) (Thysanoptera: } \\
\text { Phlaeothripidae) by RAPD markers }\end{array}$ & 2012 & Bulletin of Entomological Research \\
\hline 112 & Relationship between host plant diversity and gall-inducing insect's richness in the Brazilian Cerrado & 2012 & Neotropical Biology and Conservation \\
\hline 113 & Richness of hymenopterous galls from South America & 2012 & Papéis Avulsos de Zoologia \\
\hline 114 & Seasonal variation of natural mortality factors of the guava psyllid Triozoida limbata & 2012 & Bulletin of Entomological Research \\
\hline 115 & $\begin{array}{l}\text { Source-sink relationship and photosynthesis in the horn-shaped gall and its host plant Copaifera langsdorffii Desf. } \\
\text { (Fabaceae) }\end{array}$ & 2012 & South African Journal of Botany \\
\hline 116 & Stem galls drain nutrients and decrease shoot performance in Diplusodon orbicularis (Lythraceae) & 2012 & Arthropod-Plant Interactions \\
\hline 117 & $\begin{array}{l}\text { A new gall-inducing genus and species of Eriococcidae (Hemiptera: Sternorrhyncha: Coccoidea) on Sapindaceae from } \\
\text { Brazil }\end{array}$ & 2013 & Zootaxa \\
\hline 118 & $\begin{array}{l}\text { A new genus and species of Lasiopteridi (Diptera, Cecidomyiidae) associated with Myrciaria delicatula (Myrtaceae) from } \\
\text { Brazil, with identification keys of tribes and unplaced genera }\end{array}$ & 2013 & Biota Neotropica \\
\hline 119 & Biology and systematics of gall-inducing triozids (Hemiptera: Psylloidea) associated with Psidium spp. (Myrtaceae) & 2013 & Zootaxa \\
\hline 120 & $\begin{array}{l}\text { Comparing galling insect richness among Neotropical savannas: Effects of plant richness, vegetation structure and super- } \\
\text { host presence }\end{array}$ & 2013 & Biodiversity and Conservation \\
\hline 121 & Gall-inducing insects from Campos de Altitude, Brazil [Insetos indutores de galhas de Campos de Altitude, Brazil & 2013 & Biota Neotropica \\
\hline 122 & Gall-inducing insects from Serra do Cabral, Minas Gerais, Brazil & 2013 & Biota Neotropica \\
\hline 123 & Gall-inducing insects of an araucaria forest in southern Brazil & 2013 & Revista Brasileira de Entomologia \\
\hline 124 & Host plants of insect-induced galls in areas of cerrado in the state of Goiás, Brazil & 2013 & Acta Botanica Brasilica \\
\hline 125 & Insect galls from restingas of Southeastern Brazil, with new records & 2013 & Biota Neotropica \\
\hline 126 & Insect galls of São Tomé das Letras (MG, Brazil) & 2013 & Biota Neotropica \\
\hline 127 & Insect galls of the xeric vegetation of Ilha do Cabo Frio (Arraial do Cabo, RJ, Brazil) & 2013 & Biota Neotropica \\
\hline 128 & $\begin{array}{l}\text { Seasonal abundance of galling insects (Hymenoptera) on Caryocar brasiliense (Malpighiales: Caryocaraceae) trees in the } \\
\text { cerrado }\end{array}$ & 2013 & Florida Entomologist \\
\hline 129 & $\begin{array}{l}\text { Synchronism between Aspidosperma macrocarpon (Apocynaceae) resources allocation and the establishment of the gall } \\
\text { inducer Pseudophacopteron sp.(Hemiptera: Psylloidea) }\end{array}$ & 2013 & Revista de Biologia Tropical \\
\hline 130 & The effect of fluctuating asymmetry and leaf nutrients on gall abundance and survivorship & 2013 & Basic and Applied Ecology \\
\hline 131 & The genus Dasineura Rondani, 1840 (Diptera, Cecidomyiidae) in Brazil & 2013 & Brazilian Journal of Biology \\
\hline 132 & $\begin{array}{l}\text { Water stress and phenological synchronism between Copaifera langsdorffii (Fabaceae) and multiple galling insects: } \\
\text { Formation of seasonal patterns }\end{array}$ & 2013 & Journal of Plant Interactions \\
\hline 133 & Confirmation bias leads to overestimation of losses of woody plant foliage to insect herbivores in tropical regions & 2014 & PeerJ \\
\hline 134 & Galling insects are bioindicators of environmental quality in a conservation unit & 2014 & Acta Botanica Brasilica \\
\hline 135 & Habitat conversion and galling insect richness in tropical rainforests under mining effect & 2014 & Journal of Insect Conservation \\
\hline 136 & Insect galls of Itamonte (Minas Gerais, Brazil): Characterization and occurrence & 2014 & Biota Neotropica \\
\hline 137 & Insect galls of restinga areas of Ilha da Marambaia, Rio de Janeiro, Brazil & 2014 & Revista Brasileira de Entomologia \\
\hline 138 & Insect galls of the Parque Nacional das Emas (Mineiros, G0, Brazil) & 2014 & Check List \\
\hline 139 & Leptocybe invasa (Hymenoptera: Eulophidae), an exotic pest of Eucalyptus, in minas Gerais state, Brazil & 2014 & Florida Entomologist \\
\hline
\end{tabular}




\begin{tabular}{l} 
N Title \\
\hline 140 Local and regional determinants of galling-insect richness in neotropical savanna \\
141 Native range density, host utilisation and life history of Calophya latiforceps (Hemiptera: Calophyidae): An herbivore of \\
Brazilian Peppertree (Schinus terebinthifolia) \\
142 Patterns of cell elongation in the determination of the final shape in galls of Baccharopelma dracunculifoliae (Psyllidae) on \\
Baccharis dracunculifolia DC (Asteraceae) \\
143 Redescription of Japanagromyza inferna Spencer, first recorded from Brazil, and a key to the Neotropical species of \\
Japanagromyza Sasakawa (Diptera, Agromyzidae) \\
144 Same but different: Larval development and gall-inducing process of a non-pollinating fig wasp compared to that of \\
145 Senescent stem-galls in trees of Eremanthus erythropappus as a resource for arboreal ants \\
146 Structure of floral galls of Byrsonima sericea (Malpighiaceae) induced by Bruggmanniella byrsonimae (Cecidomyiidae, \\
Diptera) and their effects on host plants \\
147 Temporal Variation in the Sex Ratio of a Natural Population of a Multivoltine Gall-Inducing Braconid Wasp \\
148 The insect gall collection of the museu nacional/universidade federal do rio de janeiro: Biome cerrado, rupestrian fields \\
149 Unexpected high diversity of galling insects in the Amazonian upper canopy: The savanna out there \\
150 Checklist of host plants of insect galls in the state of Goiás in the Midwest Region of Brazil \\
151 Cytological cycles and fates in Psidium myrtoides are altered towards new cell metabolism and functionalities by the \\
galling activity of Nothotrioza myrtoidis
\end{tabular}

152 Descriptions of two new Pseudophacopteron species (Hemiptera: Psylloidea: Phacopteronidae) inducing galls on Aspidosperma (Apocynaceae) in Brazil

153 Detection and distribution of cell growth regulators and cellulose microfibrils during the development of Lopesia sp. galls on Lonchocarpus cultratus (Fabaceae)

154 Multivesicular bodies differentiate exclusively in nutritive fast-dividing cells in Marcetia taxifolia galls

155 New Species Diversity Revealed from Molecular and Morphological Characterization of Gall-Inducing Calophya spp. (Hemiptera: Calophyidae) from Brazilian Peppertree

156 Phenotypic plasticity and similarity among gall morphotypes on a superhost, Baccharis reticularia (Asteraceae)

157 Population dynamics of the gall inducer Eriogallococcus isaias (Hemiptera: Coccoidea: Eriococcidae) on Pseudobombax grandiflorum (Malvaceae)

158 Questioning the environmental stress hypothesis for gall diversity of restinga vegetation on dunes

159 The imbalance of redox homeostasis in arthropod-induced plant galls: Mechanisms of stress generation and dissipation

160 Clinodiplosis agerati (Diptera, Cecidomyiidae), a new galling species associated with Ageratum conyzoides (Asteraceae) from Brazil

161 Galling Insect Species Richness and Leaf Herbivory in an Abrupt Transition between Cerrado and Tropical Dry Forest

162 Galls in Schinus polygamus (Anacardiaceae): effects of forest structure on infestation intensity

163 Galls induced by Calophya latiforceps (Hemiptera: Calophyidae) reduce leaf performance and growth of Brazilian peppertree

164 Holopothrips molzi sp. n. (Thysanoptera, Phlaeothripidae): Natural history and interactions in Myrtaceae galls

165 How detrimental are seed galls to their hosts? Plant performance, germination, developmental instability and tolerance to herbivory in Inga laurina, a leguminous tree

166 Insect galls from Serra Geral, Caetité, Ba, Brazil

167 Insect galls of a protected remnant of the Atlantic Forest tableland from Rio de Janeiro State (Brazil)

168 Insect galls of Restinga de Marambaia (Barra de Guaratiba, Rio de Janeiro, RJ)

169 Insect galls on Mikania glomerata (Asteraceae) in an area of atlantic forest in Viçosa (Minas Gerais, Brazil)

170 Manipulation of host plant cells and tissues by gall-inducing insects and adaptive strategies used by different feeding guilds

171 Shifts in Plant Assemblages Reduce the Richness of Galling Insects Across Edge-Affected Habitats in the Atlantic Forest

172 The gall inducing insect community on Baccharis concinna (Asteraceae): The role of shoot growth rates and seasonal variations

173 Where host plant goes, galls go too: New records of the Neotropical galling Cecidomyiidae (Diptera) associated with Calophyllum brasiliense Cambess. (Calophyllaceae)

174 Cecidonius pampeanus, gen. et sp. n.: an overlooked and rare, new gall-inducing micromoth associated with Schinus in southern Brazil (Lepidoptera, Cecidosidae)

175 Characterization of entomogen galls from Mato Grosso do Sul, Brazil

176 Differences in leaf nutrients and developmental instability in relation to induced resistance to a gall midge

177 Experimentally reducing species abundance indirectly affects food web structure and robustness

178 Neolasioptera pantaneira, a new species of cecidomyiidae (Diptera) associated with Aeschynomene denticulata (Fabaceae) from Brazil

179 Patterns of gall infestation in Heteropterys byrsonimifolia A. Juss. in a forest-savannah ecotone

180 Plant species richness mediates the effects of vegetation structure, but not soil fertility, on insect gall richness in a savanna in Brazil

181 The role of senescent stem-galls over arboreal ant communities structure in Eremanthus erythropappus (DC.) MacLeish (Asteraceae) trees

182 Understory host plant and insect gall diversity changes across topographic habitats differing in nutrient and water stress in the Brazilian Amazon rainforest

\author{
Year Journa \\ 2014 Journal of Tropical Ecology \\ 2014 Biocontrol Science and Technology \\ 2014 Protoplasma \\ 2014 ZooKeys \\ 2014 Acta 0ecologica \\ 2014 Revista Brasileira de Entomologia \\ 2014 Plant Biology \\ 2014 Journal of Insect Behavior \\ 2014 Brazilian Journal of Biology \\ 2014 PLOSONE \\ 2015 Biodiversity Data Journal \\ 2015 Protoplasma
}

2015 Acta Entomologica Musei Nationalis Pragae

2015 Botany

2015 Protoplasma

2015 Florida Entomologist

2015 Plant Biology

2015 Journal of Natural History

2015 Revista de Biologia Tropical

2015 Biochimica et biophysica acta. G, General subjects

2016 Brazilian Journal of Biology

2016 Annals of the Entomological Society of America

2016 Brazilian Journal of Botany

2016 Biocontrol Science and Technology

2016 Zootaxa

2016 Plant Biology

2016 Biota Neotropica

2016 Revista Brasileira de Entomologia

2016 Brazilian Journal of Biology

2016 Check List

2016 Journal of Insect Physiology

2016 Environmental Entomology

2016 Lundiana

2016 Check List

2017 ZooKeys

2017 Revista Brasileira de Entomologia

2017 Arthropod-Plant Interactions

2017 Journal of Animal Ecology

2017 Brazilian Journal of Biology

2017 Revista Ceres

2017 Journal of Tropical Ecology

2017 Sociobiology

2017 Acta Amazonica 


\section{SUPPLEMENTARY MATERIAL 2}

List of inventory papers about insect galls in Brazil compiled from papers indexed in the platform "Portal de Periódicos Capes" (www.periodicos.capes.gov.br), Google Scholar and in the references of the compiled papers.

\begin{tabular}{|c|c|c|c|c|}
\hline $\mathbf{N}$ & Author & Title & Year & Journal \\
\hline 1 & Fernandes et al., 1988 & $\begin{array}{l}\text { Ocorrência e caracterização de galhas entomógenas na vegetação do campus Pampulha da Universidade } \\
\text { Federal de Minas Gerais }\end{array}$ & 1988 & Revista Brasileira de Zoologia \\
\hline 2 & Fernandes et al., 1997 & Insect-galls from savanna and rocky fields of the Jequitinhonha valley, Minas Gerais, Brazil & 1997 & Naturalia \\
\hline 3 & Gonçalves-Alvim \& Fernandes, 2001 & Comunidades de insetos galhadores (Insecta) em diferentes fisionomias do cerrado em Minas Gerais, Brasil & 2001 & Revista Brasileira de Zoologia \\
\hline 4 & Fernandes et al., 2001 & Distribution and morphology ofinsect galls of the Rio Doce Valley, Brazil & 2001 & Naturalia \\
\hline 5 & Maia, 2001 & The gall midges (Diptera, Cecidomyiidae) from three restingas of Rio de Janeiro State, Brazil & 2001 & Revista Brasileira de Zoologia \\
\hline 6 & Julião et al., 2002 & Galhas de insetos e suas plantas hospedeiras no Pantanal sul-mato-grossense & 2002 & Naturalia \\
\hline 7 & Urso-Guimarães et al., 2003 & $\begin{array}{l}\text { Occurrence and characterization of entomogen galls in plants from natural vegetation areas in } \\
\text { Delfinópolis, MG, Brazil }\end{array}$ & 2003 & Brazilian Journal of Biology \\
\hline 8 & Maia \& Fernandes, 2004 & Insect galls from Serra de São José (Tiradentes, MG, Brazil) & 2004 & Brazilian Journal of Biology \\
\hline 9 & Oliveira \& Maia, 2005 & Ocorrência e Caracterização de Galhas de Insetos na Restinga de Grumari (Rio de Janeiro, RJ, Brasil) & 2005 & Arquivos do Museu Nacional \\
\hline 10 & Urso-Guimarães \& Scareli-Santos, 2006 & Galls and gall makers in plants from the Pé de Gigante Cerrado Reserve, Santa Rita do Passa Quatro, SP, Brazil & 2006 & Brazilian Journal of Biology \\
\hline 11 & Fernandes \& Negreiros, 2006 & A comunidade de insetos galhadores da RPPN Fazenda Bulcão, Aimorés, Minas Gerais, Brasil & 2006 & Lundiana \\
\hline 12 & Moreira et al., 2007 & Galling insects as bioindicators of land restoration in an areaof Brazilian Atlantic Forest & 2007 & Lundiana \\
\hline 13 & Maia et al., 2008 & Ocorrência e caracterização de galhas de insetos em áreas de restinga de Bertioga (São Paulo, Brasil) & 2008 & Biota Neotropica \\
\hline 14 & Carvalho-Fernandes et al., 2009 & Galhas entomógenas em um fragmento urbano de Mata Atlântica no centro de endemismo de Pernambuco & 2009 & Revista Brasileira de Biociências \\
\hline 15 & Coelho et al., 2009 & Gall inducing arthropods from a seasonally dry tropical forest in Serra do Cipó, Brazil & 2009 & Revista Brasileira de Entomologia \\
\hline 16 & Carneiro et al., 2009 & Insetos indutores de galhas da porção sul da Cadeia do Espinhaço, Minas Gerais, Brasil & 2009 & Revista Brasileira de Entomologia \\
\hline 17 & Maia \& Oliveira, 2010 & Galhas de insetos da Reserva Biológica Estadual da Praia do Sul (Ilha Grande, Angra dos Reis, RJ) & 2010 & Biota Neotropica \\
\hline 18 & Bregonci et al., 2010 & Galhas de insetos do Parque Estadual Paulo CéSar Vinha (Guarapari, ES, Brasil) & 2010 & Biota Neotropica \\
\hline 19 & Santos et al., 2010 & $\begin{array}{l}\text { Ocorrência e caracterização de galhas entomógenas em uma área de floresta estacional semidecídua em } \\
\text { Goiânia, Goiás, Brasil }\end{array}$ & 2010 & Acta Botanica Brasilica \\
\hline 20 & Maia, 2011 & $\begin{array}{l}\text { Characterization of insect galls, gall makers, and associated fauna of Platô Bacaba (Porto de Trombetas, } \\
\text { Pará, Brazil) }\end{array}$ & 2011 & Biota Neotropica \\
\hline 21 & Santos et al., 2011 & Diversity of gall-inducing insects in the high altitude wetland forests in Pernambuco, Northeastern Brazil & 2011 & Brazilian Journal of Biology \\
\hline 22 & Araújo et al., 2011 & Insect galls from Serra dos Pireneus, G0, Brazil & 2011 & Biota Neotropica \\
\hline 23 & Almada \& Fernandes, 2011 & $\begin{array}{l}\text { Insetos indutores de galhas em florestas de terra firme e em reflorestamentos com espécies nativas na } \\
\text { Amazônia Oriental, Pará, Brasil }\end{array}$ & 2011 & $\begin{array}{l}\text { Boletim do Museu Paranaense Emílio } \\
\text { Goeldi de Ciências Naturais }\end{array}$ \\
\hline 24 & Santos et al., 2011 & Richness of gall-inducing insects in the tropical dry forest (caatinga) of Pernambuco & 2011 & Revista Brasileira de Entomologia \\
\hline 25 & Saito \& Urso-Guimarães, 2012 & Characterization of galls, insect galls and associated fauna of Ecological Station of Jataí (Luiz Antônio, SP) & 2012 & Biota Neotropica \\
\hline 26 & Santos et al., 2012 & $\begin{array}{l}\text { Galhas de insetos em uma área de cerrado sentido restrito na região semi-urbana de Caldas Novas } \\
\text { (Goiás, Brasil) }\end{array}$ & 2012 & Revista Brasileira de Biociências \\
\hline 27 & Santos et al., 2012 & Gall-inducing insects from Atlantic forest of Pernambuco, Northeastern Brazil & 2012 & Biota Neotropica \\
\hline 28 & Luz et al., 2012 & $\begin{array}{l}\text { Galhas de insetos em habitats xérico e mésico em região de transição Cerrado-Caatinga no norte de } \\
\text { Minas Gerais, Brasil }\end{array}$ & 2012 & Neotropical Biology and Conservation \\
\hline 29 & Malves \& Friero-Costa, 2012 & $\begin{array}{l}\text { List of plants with galls induced by insects from the UNILAVRAS/Boqueirão Biological Reserve, Ingaí, } \\
\text { State of Minas Gerais, Brazil }\end{array}$ & 2012 & Check List \\
\hline 30 & Carvalho-Fernandes et al., 2012 & The insect gall richness in preserved and anthropic areas of caatinga & 2012 & Revista Árvore \\
\hline 31 & Coelho et al., 2013 & Gall-inducing insects from Campos de Altitude, Brazil & 2013 & Biota Neotropica \\
\hline 32 & Coelho et al., 2013 & Gall-inducing insects from Serra do Cabral, Minas Gerais, Brazil & 2013 & Biota Neotropica \\
\hline 33 & Toma \& Mendonça Jr., 2013 & Gall-inducing insects of an araucaria forest in southern Brazil & 2013 & Revista Brasileira de Entomologia \\
\hline 34 & Maia, 2013 & Insect galls of São Tomé das Letras (MG, Brazil) & 2013 & Biota Neotropica \\
\hline 35 & Maia \& Souza, 2013 & Insect galls of the xeric vegetation of Ilha do Cabo Frio (Arraial do Cabo, RJ, Brazil) & 2013 & Biota Neotropica \\
\hline 36 & Costa et al., 2014 & Galhas de insetos em uma área de transição caatinga-cerrado no Nordeste do Brasil & 2014 & Sitientibus série Ciências Biológicas \\
\hline 37 & Maia et al., 2014 & Insect galls from Atlantic Forest areas of Santa Teresa, Espírito Santo, Brazil: characterization and occurrence & 2014 & Boletim do Museu de Biologia Mello Leitão \\
\hline 38 & Maia, 2014 & Insect galls of Itamonte (Minas Gerais, Brazil): Characterization and occurrence & 2014 & Biota Neotropica \\
\hline 39 & Rodrigues et al., 2014 & Insect galls of restinga areas of Ilha da Marambaia, Rio de Janeiro, Brazil & 2014 & Revista Brasileira de Entomologia \\
\hline 40 & Araújo et al., 2014 & Insect galls of the Parque Nacional das Emas (Mineiros, G0, Brazil) & 2014 & Check List \\
\hline 41 & Silva et al., 2015 & $\begin{array}{l}\text { Ocorrência e caracterização de galhas de insetos em um fragmento de mata semicaducifólia do Campus } \\
\text { Samambaia, Goiânia, G0, Brasil }\end{array}$ & 2015 & Revista de Biologia Neotropical \\
\hline 42 & Alcântara et al., 2017 & Ocorrência e caracterização de galhas em duas áreas do noroeste do Ceará, Brasil & 2015 & Natureza on line \\
\hline 43 & Carvalho-Fernandes et al., 2016 & Diversity of insect galls associated with coastal shrub vegetation in Rio de Janeiro, Brazil & 2016 & Anais da Academia Brasileira de Ciências \\
\hline 44 & Carvalho-Fernandes et al., 2016 & Insect galls from Serra Geral, Caetité, Ba, Brazil [Galhas de insetos da Serra Geral, Caetité, Bahia, Brasil] & 2016 & Biota Neotropica \\
\hline 45 & Maia \& Carvalho-Fernandes, 2016 & Insect galls of a protected remnant of the Atlantic Forest tableland from Rio de Janeiro State (Brazil) & 2016 & Revista Brasileira de Entomologia \\
\hline 46 & Maia \& Silva, 2016 & $\begin{array}{l}\text { Insect galls of Restinga de Marambaia (Barra de Guaratiba, Rio de Janeiro, RJ) [Galhas de insetos da } \\
\text { Restinga de Marambaia (Barra de Guaratiba, Rio de Janeiro, RJ)] }\end{array}$ & 2016 & Brazilian Journal of Biology \\
\hline 47 & Urso-Guimarães et al., 2017 & Characterization of entomogen galls from Mato Grosso do Sul, Brazil & 2017 & Revista Brasileira de Entomologia \\
\hline 48 & Bergamini et al., 2017 & Occurrence and characterization of insect galls in the Floresta Nacional de Silvânia, Brazil & 2017 & Papéis Avulsos de Zoologia \\
\hline
\end{tabular}

